\title{
Medgeneracijsko sobivanje mladih in starih: medkulturna primerjava
}

V članku raziskujemo, kaj vpliva na podaljšano sobivanje mladih v skupnem gospodinjstvu s starši. Zanima nas, ali mladi menijo, da bi jim država z regulativnimi ukrepi morala pri osamosvojitvi pomagati. Izhajamo iz hipoteze, da bivanje mladih in starih v razširjeni družini ni pokazatelj dobrega medgeneracijskega sožitja in solidarnosti, ampak prej izraža širše družbene in kulturne procese, ki uravnavajo življenje vse družbe in posameznikov. Raziskava je potekala v treh različnih kulturnih okoljih - v Sloveniji, Srbiji in na Japonskem. Pokazala je, da si mladi, ki bivajo v skupnem gospodinjstvu s starši, čeprav se z njimi relativno dobro razumejo, želijo »na svoje «. Pri tem pričakujejo večjo pomoč države, ki bi z regulativnimi ukrepi in pravično porazdeljeno socialno pomočjo med $\gg$ mlado « in »staro « generacijo vodila socialno bolj pravično in mladim družinam prijaznejšo stanovanjsko politiko. $S$ tem bi se zmanjšal pritisk na družino in možnosti za napetosti v njej ter tudi za napetosti med državo in družino. Največjo stopnjo strinjanja izražajo Japonci, najnižjo pa Srbi. Med finančnimi viri za nakup stanovanja slovenski udeleženci izražajo največjo stopnjo strinjanja glede financiranja $s$ kreditom, medtem ko srbski in japonski udeleženci računajo tudi na svoja finančna sredstva, kar pojasnjujemo kot značilen družbeni pojav medgeneracijskega prenosa lastninske pravice oziroma visoko izkazano pričakovanje za finančno pomočs strani sorodnikov. Ugotavljamo tudi, da bistvena medkulturna razlika glede na mesečno porabo sredstev za reševanje stanovanjskega problema lahko kaže različna pričakovanja in možnosti vstopa udeležencev v lastniški nepremičninski fond oziroma samostojno gospodinjstvo.

Ključne besede: mladi, stanovanja, sobivanje, pričakovanja, Slovenija, Srbija, Japonska 


\section{Uvod}

Gospodarske, družbene, kulturne, politične in demografske spremembe pomembno vplivajo na tradicionalno družino, družbene strukturne in medgeneracijske odnose (Ramovš, 2013). Navedeno se kaže v vse aktualnejšem problemu skupnega gospodinjstva oziroma podaljšanega sobivanja mladih, mladih družin in staršev. Problem je vse pogosteje tematiziran na politični in tudi na raziskovalni ravni. Kdaj bo prišlo do odhoda od doma ter $\mathrm{v}$ kakšno stanovanje in življenjsko ureditev bo to peljalo, je odvisno od številnih osebnih in družbenih okoliščin. Kot navaja Srna Mandič (2007), so ti dejavniki po eni strani individualni in segajo na mikroraven, na kateri so pomembni posameznikove želje, izbire in viri; po drugi strani pa so dejavniki strukturni ter na makroravni določajo številne priložnosti in ovire, $s$ katerimi se posamezniki soočajo pri svojih izbirah v okolju. Strukturni dejavniki so povezani z značilnostmi okolja in pojasnjujejo, zakaj posamezniki v isti družbi sledijo podobnim vzorcem odhoda od doma in zakaj se ti vzorci med državami razlikujejo. Ti dejavniki so razmeroma dobro raziskani (Mandič, 2009; Kuhar, 2012; Emmons in Noeth, 2014, in Bratina Jurkovič, 2014). Hkrati pa je odraščanje, ki je bilo v preteklosti pretežno standardizirano in predvidljivo, $\mathrm{v}$ sodobnih razmerah postalo individualni projekt, za katerega je odgovoren vsak sam, kar pa ne pomeni, da pri vzpostavljanju razmer za uspešno uresničitev prehoda mladih v odraslost ni pomembna vloga države in širše družbe (Lavrič, 2011). V raziskavi nas zanima, ali mladi menijo, da bi jim država z regulativnimi ukrepi morala pri osamosvojitvi pomagati. Raziskujemo razloge za bivanje mladih v skupnem gospodinjstvu s starši ter v tem okviru analiziramo njihovo željo, namen, način in pričakovanja po odselitvi »na svoje «. Izhajamo iz hipoteze, da bivanje mladih in starih $\mathrm{v}$ razširjeni družini ni pokazatelj dobrega medgeneracijskega sožitja in solidarnosti, ampak prej izraža širše družbene in kulturne procese, ki uravnavajo življenje vse družbe in posameznikov. Alan Walker (2006) celo trdi, da oblikovalci politik ne razumejo temeljnega pomena medgeneracijske solidarnosti, temveč ga dojemajo le kot finančno-rabni odnos. Meni, da razmišljanja in usmeritve, da so družbene investicije in izobraževanje predvsem za mlade, izhajajo iz stare paradigme družbe treh generacij. To pa lahko povzroča nevarnost medgeneracijskih napetosti, saj s tem razdeljevalci javnih financ socialne države privilegirajo določene družbene skupine. Tako mlada kot stara generacija imata svoje potrebe, ki pa jih bo, še posebej v času upočasnjene gospodarske rasti vse težje zadovoljiti iz virov socialne države. Kot povzema Ksenija Ramovš (2013), lahko to vodi v napetosti med njima. $\mathrm{V}$ okviru tega nas zanima, kako zadovoljni so mladi s svojimi trenutnimi bivalnimi razmerami v skupnem gospodinjstvu. Vincent R. Waldron idr. (2005) pišejo o trendu socializacije starejše populacije v novih okoljih, vendar hkrati opozarjajo na njeno izrazito navezanost na domače okolje. Družinsko okolje se povezuje s skupno zgodovino, bližnjimi medgeneracijskimi odnosi in družinsko tradicijo, izraža sobivanje in skrb za starejše sorodnike kot naravno nadaljevanje tradicije in recipročno medgeneracijsko podporo v vsakdanjem življenju (Jolanki, 2015). Zanima nas, ali ta navezanost pogojuje tudi medsebojno bivalno soodvisnost.

Kot sklepata Miran Lavrič in Rudi Klanjšek (2013), je predvsem $\mathrm{v}$ državah $\mathrm{z}$ liberalno ureditvijo prehodov mladih $\mathrm{v}$ lastno gospodinjstvo in $s$ tem povezanim zgodnjim odhodom od doma tveganje revščine za mlade, ki ne živijo pri starših, bistveno večje v primerjavi s tistimi, ki ostajajo doma. $V$ državah $s$ subprotektivno (mediteransko) ureditvijo teh razlik skoraj ni. Številni raziskovalci (Aassve idr., 2006) ugotavljajo, da je to mogoče pojasniti samo $s$ kulturnimi dejavniki. Naša raziskava je potekala v treh različnih kulturnih okoljih - v Sloveniji, Srbiji in na Japonskem. Merili za izbor sta bili različna gospodarska razvitost držav in njihova različna strateška lega (Slovenija kot del EU, Srbija kot del nekdanje Socialistične federativne republike Jugoslavije in Japonska kot tehnološko visoko razvita azijska država). V raziskavi je sodelovalo 1.006 slovenskih udeležencev, 385 srbskih in 264 japonskih.

\section{Strukturni in individualni dejavniki sobivanja}

K raziskavi so nas spodbudili rezultati številnih študij, ki med drugim kažejo, da skoraj polovica mladih Evropejcev, starih od 15 do 30 let, živi pri starših (Eurostat, 2012). 26 \% jih navaja, da se ne odselijo, ker nimajo na voljo dovolj cenovno ugodnih stanovanjskih možnosti, $11 \%$, da živijo v gospodinjstvu staršev zaradi stanovanjskih ugodnosti, ne da bi jim bilo treba zanje prevzeti odgovornost, in $10 \%$, da živijo doma, ker se bodo čez čas poročili oziroma odselili s partnerjem. Le $3 \%$ mladih, starih do 30 let, živi doma zato, ker finančno skrbi za starše. Slovenija po številu mladih (25-34 let), ki živijo pri starših, spada v sam vrh evropskih držav. Po podatkih Eurostata (2012) v njej kar 43,5\% mladih v tej starostni skupini še vedno živi doma. Po raziskavi European Union Labour Force Survey (2013), ki ponuja primerjave za države članice Evropske unije, je Slovenija glede dolžine skupnega bivanja staršev in otrok na drugem mestu v Evropi, takoj za Slovaško (celo pred Italijo). Raziskave sicer kažejo, da mladi v Evropi danes pozneje dosegajo mejnike odraščanja, kot so stabilna služba, finančna stabilnost, stanovanjska neodvisnost in stabilno partnerstvo (Ule in Kuhar, 2003). Odlašanje z odselitvijo od izvorne družine je značilno za vso Evropo (Biggart idr., 2004; Holdsworth in Morgan, 2006, ter Pompe in Temeljotov Salaj, 2014). Mirjana Ule in Metka Kuhar (2003) v raziskavi prav tako ugotavljata, da anketiranci med najpogostejšimi razlogi 
za podaljšano bivanje pri starših navajajo nerešen stanovanjski problem. M. Kuhar (2013) kot ključne razloge za podaljševanje medgeneracijskega sobivanja v Sloveniji navaja majhno število finančno dostopnih stanovanj, slabo razvit trg dela ter prakso, ki je določena s kulturo in povezana s širšimi dejavniki strukturne oziroma institucionalne narave, zlasti z dostopnostjo državnih podpor v razmerju do družinskih. Hkrati je povečano obilje zadnjih desetletij povzročilo, da prvič v zgodovini velik del evropske populacije prenaša svoje sorazmerno veliko premoženje na generacijo otrok (Brandt idr., 2008). Vse navedeno vpliva na aktualen pojav podaljšanja sobivanja mladih družin in staršev. Večina avtorjev pa meni, da je treba gledati na družino s komplementarnega vidika, kar pomeni, da če država omogoči družinam funkcionalno pomoč, jo s tem razbremeni (Ramovš, 2013). Kot navaja Walter Korpi (2000), se s tem zmanjša pritisk na družino in tudi možnost za napetosti v njej, kot tudi za napetosti med državo in družino.

Prehod iz stanovanja staršev v samostojno stanovanje lahko raziskujemo v različnih okvirih, nas pa problem zanima predvsem kot vprašanje stanovanjske kariere. Gre torej za vprašanje, v kateri tip stanovanjske oskrbe spada prvo samostojno stanovanje. V nekaterih državah ima pomembno vlogo najemniški tip stanovanj, na primer na Nizozemskem in v Nemčiji (Mulder, 2006), v državah Južne Evrope pa je na poti do samostojnega stanovanja najpomembnejša gradnja v lastni režiji, pogosto s pomočjo sorodnikov (Allen idr., 2004). Kot navaja S. Mandič (2007), slednje velja tudi za Slovenijo. Christian Mulder (2006) kot glavno oviro za dostopnost stanovanj za mlade krivi visok odstotek lastniških stanovanj, slabo kreditno politiko in visoke cene stanovanj. $\mathrm{V}$ tranzicijskih državah lahko razumemo podaljš̌nje bivanja pri starših celo kot » kolateralno škodo « stanovanjske reforme, ki je zelo radikalno zmanjšala javni najemni sektor stanovanj, pričakovanja od zasebnega pa se s tega zornega kota ne kažejo kot dovolj realistična (Mandič, 2007, ter Mandič in Filipovič Hrast, 2015). Starši naj bi bili tisti, ki se trudijo zapolniti posledice razgradnje predhodne univerzalne države blaginje (Kovacheva, 2006). Hkrati pa, kot ugotavljata M. Ule in M. Kuhar (2003), mladi v povprečju uživajo doma pri starših dobršno mero avtonomije, tako da lahko podaljšano bivanje z njimi vsaj do določene mere razumemo kot izbran življenjski slog, povezan z udobnostjo v slogu »hotela mama «. Ko sledimo hipotezi, da bivanje mladih in starih v razširjeni družini ni pokazatelj dobrega medgeneracijskega sožitja in solidarnosti, nas zanimajo njihovi individualni razlogi za sobivanje in dejavniki, ki vplivajo na to. Zanima nas, kako mladi gledajo na sobivanje in kakšna so njihova pričakovanja glede reševanja stanovanjskega problema. Kot navajajo Ronald Goetegeluk idr. (1992), se gospodinjstvo odloči za drugo stanovanje, če mu to prinese več koristi kot bremen v primerjavi s prejšnjim stanovanjem. $V$ tem kontekstu je pomembna tudi povezava med zaposlitvijo in stanovanjem ter s tem stanovanjska mobilnost. Kot navaja S. Mandič (2009), ima stanovanjska mobilnost na splošno pozitivno konotacijo, saj naj bi višja mobilnost izražala dejstvo, da se več gospodinjstev preseljuje v stanovanja, ki so primernejša zanje. $V$ razvitem gospodarstvu se številna gospodinjstva celo odločajo, da iščejo hkrati stanovanjske in zaposlitvene priložnosti, in izberejo tisto, kar daje najboljšo skupno kombinacijo (van Ommerren idr., 2000, in Yau, 2015). Statistični podatki za Slovenijo kažejo zelo nizko stanovanjsko mobilnost, kar povezujemo z omejeno dostopnostjo stanovanjskih virov, zlasti najemniških stanovanj. Pri tem so pomembni dejavniki še izrazita prevlada lastniških stanovanj, močno razvita samooskrbna praksa, razpršena lastništva zemljišč in v preteklosti zelo liberalen urbanistični red.

Za Japonsko Ge Jian in Hokao Kazunori (2004) ugotavljata vpliv regionalnih lastnosti in osebnih stanovanjskih preferenc na vrednotenje stanovanjskih okolij v lokalnih mestih. Avtorja sta raziskovala dejavnike, ki vplivajo na življenjski slog $\mathrm{v}$ japonskih mestih z vidika zadovoljstva uporabnikov nepremičnin, njihovih preferenc in možnosti izbire pri nakupu nepremičnin (Jian in Kazunori, 2006). Glede na preference pri iskanju kraja bivanja sta določila tri glavne tipe udeležencev, in sicer tiste, ki pri iskanju stanovanja dajejo večjo prednost urbanemu kot naravnemu okolju, uživajo v službenem okolju (delu) in so na prvem mestu pripravljeni vlagati v standard neposredne okolice stanovanja, sledijo udeleženci, ki dajejo prednost neurbanemu okolju, imajo raje vsakdanje življenje kot službo in so najprej pripravljeni vlagati v stanovanje, tretji tip udeležencev združuje lastnosti obeh prejšnjih, pri izbiri kraja bivanja pa daje prednost družbenim dejavnostim in medosebnim odnosom. Za Japonsko je značilno, da se je od leta 1970 naprej delež nikoli poročenih ljudi izjemno povečeval (v starosti 30-34 let z 11,6 na $42,9 \%$ za moške in s 7,2 na $26,6 \%$ za ženske). $V$ tem obdobju se je bistveno povečala tudi starost pri prvi poroki, in sicer s 27,5 na 30,8 leta za moške in s 24,7 na 28,6 leta za ženske (National Institute of Population and Social Security Research, 2008). Podobni trendi so opazni tudi v Evropi, vendar pa ti niso tako izraziti. Raziskovalci poznejšo poroko in večji delež neporočenih $\mathrm{v}$ evropskih deželah povezujejo z različnimi (spremenjenimi) življenjskim razmerami (Goldscheider, 1997, ter Bianchi in Casper, 2000). Kar pa, kot ugotavlja Setsuya Fukuda (2007), ni značilno za Japonsko. Številni znanstveniki raziskujejo razloge, zaradi katerih mladi Japonci ostajajo dalj časa doma (Takahashi in Voss, 2000; Takada, 2004; Fukuda, 2007, in Suzuki 2007), in kakšne demografske posledice prinaša to (Raymo, 2003; Raymo in Ono, 2004, in Suzuki, 2007). Ugotovili so, da je za Japonsko značilno, da se ženske poročajo pri nižji starosti kot moški, zdi pa se, da je to edina država, v kateri moški prej zapuščajo dom staršev. Kot vzrok za to navajajo šolanje in zaposlitev, kot glavna ovira za to, da gredo mladi na svoje, pa se poudarjajo finance. Vzpostavitev novega gospodinjstva je na Japonskem zelo draga. 
Misa Izahura (2014) ugotavlja, da je vzrok za poznejši odhod od doma povezan predvsem $z$ gospodarsko recesijo in širšo neoliberalistično globalizacijo. Ženske, ki so se prej poročale pri 20., se zdaj pri 30., kar so tudi leta, pri katerih se odločajo za nakup stanovanja. Lastništvo jim pomeni predvsem uporabno vrednost in zagotovitev varnosti v zrelih letih.

Kot navajata Smiljka Tomanović in Suzana Ignjatović (2006), je za Srbijo znacilno, da mladi povezujejo prehod v svoje gospodinjstvo z ustvarjanjem družine in ne toliko z neodvisnim življenjskim slogom. Ugotavljajta, da skoraj petina mladih anketirancev navaja, da je poroka (nosečnost) glavni pogoj za začetek skupnega življenja s partnerjem in $s$ tem za odhod $\mathrm{v}$ svoje gospodinjstvo. Drugi predpogoji za osamosvojitev od staršev so še dober dohodek, delovno mesto in dosegljivost lastnega stanovanja. Pri mladih v Srbiji ne obstaja neskladje med normativno in praktično ravnjo pri prehodu $\mathrm{v}$ odraslost. Tvorba družine se šteje kot neke vrste »strategija « pri prehodu v odraslost. Po navedbah avtoric mladi v Srbiji svojega odhoda od doma ne vidijo kot konec življenjskega sloga, odvisnega od staršev, temveč kot predpogoj za prehod v odraslost. Ta vzorec je v nasprotju z evropskim trendom, pri katerem neodvisnost od staršev oziroma odselitev na svoje ne pomeni nujno tudi začetka ustvarjanja lastne družine (Heath, 1999).

Joachim Vogel (2002) je empirično ugotovil, da se družbe z različnimi tipi konstelacije blaginje razlikujejo tudi po starosti, pri kateri mladi odhajajo iz bivališča staršev. Ugotovil je tudi, da v družbah, za katere je značilno šibko delovanje trga dela (težek vstop mladih na trg dela) in šibki ukrepi države blaginje pri blaženju tveganj (nizki izdatki za socialno varnost), mladi zapuščajo dom staršev najpozneje. Nada Stropnik in Milivoja Šircelj (2008) ugotavljata, da sta stanovanjska in zaposlitvena kariera mladih povezani. Mladi tako ostajajo pri starših, dokler jim zaposlitvena kariera ne omogoči finančne neodvisnosti, da lahko najamejo stanovanjski kredit in si tako uresničijo prevladujoči lastniški status. Kako skupne družinske finance vplivajo na to in kdaj mlade družine zapustijo gospodinjstvo staršev, je težko napovedati (Hartley, 1993). Številne države se srečujejo z demografskimi spremembami, kot sta hitro se starajoče se prebivalstvo in padanje rodnosti. N. Stropnik in M. Šircelj (2008) poudarjata, da med drugim tudi odselitev iz gospodinjstva staršev pomembno vpliva na rodnost. Kot navaja Miran Lavrič (2011), ima v Sloveniji pri 29. letih vsaj enega otroka $50 \%$ mladih, ki živijo v samostojnem gospodinjstvu, od mladih, ki pri teh letih živijo pri starših, pa le dobrih $15 \%$. Zdi se, da država, namesto da bi mladim ponudila neprofitna stanovanja, sili te v lastništvo, ki pa si ga ne morejo privoščiti. To jim prav tako preprečuje, da bi se osamosvojili in imeli otroke.

\section{Metoda in udeleženci}

Uporabili smo metodo, ki temelji na vprašalniku (Walonic, 2007), ki smo ga sestavili v sklopu širše raziskave. Potekala je $\mathrm{v}$ različnih kulturnih okoljih in njen temeljni cilj je bil določiti dejavnike, ki so za potencialne pridobitelje nepremičninskih pravic odločilni pri odločanju o nakupu nepremičnine (Grum, 2014, ter Grum in Kobal Grum, 2015). Od treh glavnih tipov vprašanj (Keats, 2000) - odprta vprašanja (udeležencu dopuščajo popolno svobodo pri odgovoru), vprašanja $\mathrm{z}$ večjo izbiro odgovorov (udeleženec izbere najprimernejši odgovor) in vprašanja z odgovori po vrsti (Likertova lestvica) - sta bila uporabljana zadnja dva. Udeleženci so izražali stališča s pomočjo Likertove petstopenjske lestvice od 1 (popolnoma nepomembno) do 5 (zelo pomembno). Podatki so bili obdelani s statističnim programom SPSS. Statistična analiza zajema faktorsko analizo vprašalnika, analizo zanesljivosti vprašalnika (Cronbachov-alfa), opisno statistiko in analize variance (Grum in Temeljotov Salaj, 2010b). Sklop vprašalnika, ki meri demografske značilnosti, zajema 34 spremenljivk. Ekstrahirali smo osem dejavnikov, ki pojasnijo več kot $60 \%$ variance (Grum in Temeljotov Salaj, 2010a). Kaiser-Meyer-Olkinova mera adekvatnosti vzorčenja je 0,759 , kar pomeni, da so merjene spremenljivke dobro psihometrično povezane (Fulgosi, 1984). Tudi Bartlettov test $(B T=2178,119)$, ki je statistično značilen, kaže, da je ekstrahirane dejavnike mogoče interpretirati (Fulgosi, 1984).

V raziskavi je sodelovalo 1.006 slovenskih udeležencev, 385 srbskih in 264 japonskih. Stari so bili od 20 do 40 let, razdeljeni po spolu, izobrazbi, družbenem in finančnem položaju, zakonskem oziroma družinskem položaju, bivalnem okolju in kulturni pripadnosti. Zbiranje podatkov je v prvi fazi potekalo prek spleta. V nasprotju s slovenskimi udeleženci se je pri japonskih in srbskih udeležencih pokazalo veliko nezaupanje do sodelovanja pri spletnih anketah. Zaradi tega smo pri zbiranju podatkov v drugi fazi uporabili metodo snežne kepe (Lobe, 2006). Pri uporabi te vrste vzorčenja se za izgradnjo vzorca proučevane skupine uporabljajo osebna poznanstva. Izbere se manjši vzorec oseb, ki odgovarjajo na vprašalnik, hkrati pa $\mathrm{k}$ izpolnjevanju povabijo svoje znance (Klinc idr., 2010). Vsak naslednji anketiranec naj bi zagotovil nekaj novih anketirancev. Prednost tega vzorčenja je predvsem hitro popolnjevanje vzorca, ki pa je odvisen samo od začetne izbire populacije. To je hkrati tudi slabost, saj po začetni izbiri vzorca nad njim nimamo več nadzora. Dodatna slabost je tudi odvisnost od posameznikovega mreženja $\mathrm{v}$ horizontalni in predvsem $\mathrm{v}$ vertikalni smeri. Pri pridobivanju japonskih udeležencev je težave povzročalo tudi dejstvo, da na Japonskem distribucija vprašalnika na javnih mestih ni dovoljena (brez odobritve posebne etične komisije). Posledica tega je različno velik vzorec pri različnih kulturah. Zbiranje podatkov je trajalo od novembra 2013 do 
Preglednica 1: Struktura udeležencev glede na demografske značilnosti

\begin{tabular}{|c|c|c|c|c|c|c|}
\hline pripadnost kulturi & Slovenci & & Srbi & & Japonci & \\
\hline Slovenija, Japonska, Srbija & število & odstotek & število & odstotek & število & odstotek \\
\hline \multicolumn{7}{|l|}{ spol } \\
\hline ženske & 623 & 61,93 & 276 & 71,88 & 90 & 34,09 \\
\hline moški & 383 & 38,07 & 108 & 28,13 & 174 & 65,91 \\
\hline skupaj & 1.006 & 100,00 & 384 & 100,00 & 264 & 100,00 \\
\hline \multicolumn{7}{|l|}{ starost } \\
\hline od 20 do 29 let & 490 & 48,71 & 222 & 57,81 & 114 & 43,18 \\
\hline od 30 do 40 let & 516 & 51,29 & 162 & 42,19 & 150 & 56,82 \\
\hline skupaj & 1.006 & 100,00 & 384 & 100,00 & 264 & 100,00 \\
\hline \multicolumn{7}{|l|}{ družinski položaj } \\
\hline samski & 264 & 26,53 & 178 & 46,35 & 168 & 65,12 \\
\hline v zvezi oziroma poročen & 731 & 73,47 & 206 & 53,65 & 90 & 34,88 \\
\hline skupaj & 995 & 100,00 & 384 & 100,00 & 258 & 100,00 \\
\hline \multicolumn{7}{|l|}{ lokacija trenutnega bivališča } \\
\hline v središču mesta & 316 & 31,76 & 208 & 54,17 & 114 & 44,19 \\
\hline na obrobju mesta & 321 & 32,26 & 144 & 37,50 & 132 & 51,16 \\
\hline v strnjenem podeželskem naselju & 234 & 23,52 & 18 & 4,69 & 6 & 2,33 \\
\hline v razpršenem podeželskem naselju & 116 & 11,66 & 0 & 0,00 & 0 & 0,00 \\
\hline drugje & 8 & 0,80 & 14 & 3,65 & 6 & 2,33 \\
\hline skupaj & 995 & 100,00 & 384 & 100,00 & 258 & 100,00 \\
\hline \multicolumn{7}{|l|}{ trenutno živite v: } \\
\hline lastnem ali solastniškem stanovanju & 531 & 53,64 & 258 & 67,19 & 72 & 27,91 \\
\hline tržnem najemniškem stanovanju & 99 & 10,00 & 82 & 21,35 & 96 & 37,21 \\
\hline neprofitnem najemniškem stanovanju & 27 & 2,73 & 0 & 0,00 & 24 & 9,30 \\
\hline pri starših & 269 & 27,17 & 24 & 6,25 & 54 & 20,93 \\
\hline drugo & 64 & 6,46 & 20 & 5,21 & 12 & 4,65 \\
\hline skupaj & 990 & 100,00 & 384 & 100,00 & 258 & 100,00 \\
\hline \multicolumn{7}{|l|}{ mesečna poraba dohodka za bivališče: } \\
\hline nič & 450 & 45,73 & 278 & 72,40 & 60 & 23,26 \\
\hline manj kot $30 \%$ dohodka & 216 & 21,95 & 38 & 9,90 & 150 & 58,14 \\
\hline okoli $30 \%$ dohodka & 149 & 15,14 & 34 & 8,85 & 24 & 9,30 \\
\hline več kot $30 \%$ dohodka & 129 & 13,11 & 32 & 8,33 & 24 & 9,30 \\
\hline skoraj ves dohodek & 40 & 4,07 & 2 & 0,52 & 0 & 0,00 \\
\hline skupaj & 984 & 100,00 & 384 & 100,00 & 258 & 100,00 \\
\hline \multicolumn{7}{|l|}{ zadovoljstvo z bivalnimi pogoji } \\
\hline zelo nezadovoljen & 76 & 7,74 & 55 & 14,32 & 30 & 11,63 \\
\hline nezadovoljen & 105 & 10,69 & 38 & 9,90 & 24 & 9,30 \\
\hline srednje zadovoljen & 220 & 22,40 & 46 & 11,98 & 48 & 18,60 \\
\hline zadovoljen & 281 & 28,62 & 76 & 19,79 & 90 & 34,88 \\
\hline zelo zadovoljen & 300 & 30,55 & 92 & 23,96 & 66 & 25,58 \\
\hline skupaj & 982 & 100,00 & 384 & 100,00 & 258 & 100,00 \\
\hline
\end{tabular}

maja 2014. Struktura udeležencev glede na njihove demografske značilnosti je prikazana v preglednici 1 .

Iz preglednice je razvidno, da je v nasprotju s Slovenijo in Srbijo med Japonci največ udeležencev moškega spola (65,91 \%). Za japonsko kulturno okolje različni avtorji ugotavljajo (For- rest idr., 2003, in Hirayama, 2008), da ni presenetljivo, da obstajajo razlike med spoloma $\mathrm{v}$ stopnji lastništva stanovanj, saj šele zadnji dogodki, povezani z gospodarsko krizo na Japonskem (padec vrednosti premoženja, nižje obrestne mere, deregulacije posojil, spremenjena pravila v povezavi s poznejšo poroko), omogočajo lastništvo tudi samskim ženskam. 
Glede starostne strukture pri Srbih prevladujejo mlajši udeleženci $(57,81 \%)$, medtem ko je struktura pri Slovencih in Japoncih podobna. Pri Japoncih je največ udeležencev samskih $(65,12 \%)$, kar pojasnjujemo z ugotovitvami nekaterih raziskav (Deutsch, idr., 2005), da je povprečna starost Japonca, ko vstopa v svoje gospodinjstvo, blizu 40 let, kar je visoko v primerjavi z Ameriko (29 let) ali Avstrijo (31 let). Raziskave tudi kažejo (Deutsch, idr., 2005), da je tako stanje posledica bančne politike - ki določa maksimalno obremenitev lastnega dohodka do $25 \%$ in minimalno lastno udeležbo pri nakupu nepremičnine do višine $20 \%$ vrednosti nepremičnine - in visokih cen nepremičnin, saj mora japonski kupec za stanovanje plačati povprečno 8,5 celoletnega dohodka.

Glede na lastništvo stanovanja opažamo med udeleženci pomembne razlike. Največ lastnikov stanovanj je med Srbi $(67,19 \%)$, med Slovenci je teh 53,64 \%, med Japonci pa $27,91 \%$. Navedeno pojasnjujemo z lastniško strukturo stanovanjskega fonda v izbranih državah, ki kaže, da je Srbija leta 2010 imela dobrih $90 \%$ lastniških stanovanj, Slovenija dobrih 80 \% in Japonska dobrih $64 \%$. Bistvena razlika se pojavlja v odstotku udeležencev, ki bivajo pri starših. Kar 27,17 \% slovenskih udeležencev (starih od 20 do 40 let) živi v skupnem gospodinjstvu s starši, nekoliko nižji je odstotek japonskih udeležencev $(20,93 \%)$, medtem ko z izjemno nizkim odstotkom izstopajo srbski udeleženci (6,25 \%). Podatki tudi sicer kažejo, da je Slovenija po številu mladih (25-34 let), ki živijo pri starših, na vrhu lestvice. Po podatkih Eurostata (2012) v Sloveniji kar 43,5\% mladih v tej starostni skupini še vedno živi doma, tako ta spada $\mathrm{v}$ sam vrh evropskih držav glede podaljšanega sobivanja staršev in mladih. Iz preglednice 1 je razvidno, da je večina udeležencev navedla, da za reševanje stanovanjskega problema porabi manj kot $30 \%$ dohodka, zelo visok odstotek Slovencev $(45,73 \%)$ in še večji Srbov $(72,40 \%)$ pa, da za to ne porabi nič. Iz navedenega lahko razberemo, da Slovenci in Srbi v kratkem ne nameravajo kupiti novega stanovanja (ne varčujejo), vzroke za to pa lahko pripišemo tudi trenutni gospodarski krizi in finančni (ne)moči udeležencev.

Da se pričakovanja kupcev spreminjajo $s$ spremembo gospodarskega stanja na trgu nepremičnin, sta ugotovila tudi Joseph T. Y. Wong in Eddie C. M. Hiu (2006), ki navajata, da so težnje kupcev bolj optimistične, kadar cene na nepremičninskem trgu rastejo, in bolj pesimistične, kadar te padajo. Dokler udeleženci pričakujejo rast cen na nepremičninskem trgu, njihovo vedenje ustvarja višje zahteve (Wong in Hiu, 2006, Sangarun, 2013, ter Hoxha, idr., 2014). Glede zadovoljstva najvišje zadovoljstvo izražajo Slovenci, najnižje pa Srbi, med katerimi je zelo nezadovoljnih s svojim trenutnim stanovanjskim položajem kar 14,32 \%. William Rohe idr. (2001) so v študiji ameriških kupcev nepremičnin ugotovili, da je pri lastnikih stanovanj občutek samozadovoljstva višji kot pri udeležencih, ki bivajo v najemniških stanovanjih. Tudi Reinout Kleinhans in Marja Elsinga (2010) ugotavljata, da ostaja močna povezava med lastništvom doma in občutkom samozadovoljstva.

\section{Rezultati in interpretacija}

Rezultate smo statistično analizirali z analizo variance. Ta statistična metoda oziroma statistični test se $\mathrm{v}$ raziskavah pogosto uporablja, tako kot $t$-test za neodvisne vzorce, le da lahko pri njej primerjamo povprečja treh skupin ali več. Kot odvisne spremenljivke smo izbrali pripadnost kulturi, starost in stanovanjski položaj, in sicer glede na osnovne demografske značilnosti udeležencev (izobrazba, spol, družinski položaj, kraj bivanja, zaposlitev, povprečna mesečna poraba sredstev za reševanje stanovanjskega problema, zadovoljstvo $s$ trenutnimi bivalnimi pogoji, stroški vzdrževanja) in glede na njihova pričakovanja ob ustvarjanju lastnega gospodinjstva (socialna varnost, družbeni položaj, občutek samostojnosti in samozadovoljstva, pričakovani regulativni ukrepi države in pričakovani finančni viri. Statistično pomembne razlike glede na pripadnost kulturi, starost in stanovanjski položaj (udeleženec živi v svojem stanovanju, v najemniškem stanovanju, pri starših ali drugje) so prikazane v preglednici 2.

Statistično pomembne razlike na ravni $p<0,05$ se kažejo pri spolu in vprašanju glede pričakovanja pomoči države $\mathrm{v}$ okviru njenih regulativnih ukrepov. Statistično pomembne razlike na ravni $p<0,01$ se kažejo glede na izraženo zadovoljstvo $s$ trenutnimi stanovanjskimi pogoji in glede izraženega občutka samostojnosti. Statistično pomembne razlike na ravni $p<0,001$ se kažejo glede na družinski položaj, mesečno porabo za reševanje stanovanjskega problema in pri načrtovanih glavnih virih pri nakupu lastnega stanovanja. Zanimivo pa je, da so korelacije med dejavniki glede na stanovanjski položaj udeležencev šibke, saj nobena od absolutnih vrednosti ni večja od 0,9.

Najmočnejša korelacija se izraža med stanovanjskim in družinskim položajem $(-0,181)$, pri čemer negativna korelacija nakazuje, da samski udeleženci v večji meri živijo v skupnem gospodinjstvu s starši kot udeleženci v zvezi. Zanimiva je tudi negativna korelacija med stanovanjskim položajem in zadovoljstvom s trenutnimi stanovanjskimi pogoji $(-0,188)$, ki kaže, da so udeleženci, ki živijo pri starših, bolj nezadovoljni kot udeleženci, ki bivajo v svojem ali najemniškem stanovanju. Pričakovana pozitivna korelacija med stanovanjskim položajem in občutkom samostojnosti $(0,167)$ kaže, da udeleženci, ki živijo v skupnem gospodinjstvu s starši, izražajo višja pričakovanja glede tega, da bi v svojem gospodinjstvu (v svojem najemniškem ali lastniškem stanovanju) imeli večji občutek samostojnosti.

Povprečne stopnje strinjanja pri dejavnikih, pri katerih se kažejo statistično pomembne razlike glede na pripadnost kulturi, 
Preglednica 2: Statistično pomembne razlike glede na pripadnost kulturi, starost in stanovanjski položaj

\begin{tabular}{|c|c|c|c|c|c|c|}
\hline spremenljivke & & vsota kvadratov & $d f$ & srednji kvad. & $F$ & $p$ \\
\hline izobrazba & & 1,755 & 6 & 0,293 & 0,788 & 0,580 \\
\hline spol & * & 3,431 & 6 & 0,572 & 2,634 & 0,015 \\
\hline družinski položaj & $* * *$ & 4,731 & 6 & 0,789 & 4,231 & 0,000 \\
\hline kje živite (lokacija) & & 6,699 & 6 & 1,117 & 1,419 & 0,204 \\
\hline zaposlitev & & 4,121 & 6 & 0,687 & 2,017 & 0,060 \\
\hline mesečna poraba dohodka za stan. & $* * *$ & 32,351 & 6 & 5,392 & 6,125 & 0,000 \\
\hline zadovoljstvo s stan. položajem & $* *$ & 26,794 & 6 & 4,466 & 3,390 & 0,003 \\
\hline stroški vzdrževanja & & 12,557 & 6 & 2,093 & 1,895 & 0,078 \\
\hline občutek varnosti & & 4,954 & 6 & 0,826 & 0,857 & 0,526 \\
\hline občutek socialne varnosti & & 6,688 & 6 & 1,115 & 0,950 & 0,458 \\
\hline občutek boljšega družbenega položaja & & 9,064 & 6 & 1,511 & 1,516 & 0,169 \\
\hline občutek samostojnosti & ** & 17,9 & 6 & 2,983 & 2,856 & 0,009 \\
\hline občutek samozadovoljstva & & 9,56 & 6 & 1,593 & 1,413 & 0,206 \\
\hline glavni finančni viri pri nakupu nepremičnine & $* * *$ & 37,971 & 6 & 6,329 & 5,995 & 0,000 \\
\hline pričakovanost pozitivnih regulativnih ukrepov & * & 13,563 & 6 & 2,260 & 2,248 & 0,037 \\
\hline
\end{tabular}

Opombe:

* Razlika je statistično pomembna $(p<0,05)$.

** Razlika je statistično pomembna $(p<0,01)$.

*** Razlika je statistično pomembna $(p<0,001)$.

Preglednica 3: Korelacije med spremenljivkami glede na pripadnost kulturi in stanovanjski položaj

\begin{tabular}{lllllllll}
\hline & spol & $\begin{array}{l}\text { družinski } \\
\text { položaj }\end{array}$ & $\begin{array}{l}\text { stanovanjski } \\
\text { položaj }\end{array}$ & $\begin{array}{l}\text { mesečna } \\
\text { poraba }\end{array}$ & zadovoljstvo & samostojnost & finančni viri & $\begin{array}{l}\text { regulativni } \\
\text { ukrepi }\end{array}$ \\
\hline spol & 1,000 & $-0,075$ & $-0,065$ & 0,080 & $-0,075$ & $-0,180$ & $-0,134$ & 0,069 \\
\hline družinski položaj & $-0,075$ & 1,000 & $-0,181$ & 0,154 & 0,012 & $-0,097$ & $-0,002$ & 0,012 \\
\hline stan. položaj & $-0,065$ & $-0,181$ & 1,000 & $-0,068$ & $-0,188$ & 0,167 & 0,035 & 0,007 \\
\hline mesečna poraba & 0,080 & 0,154 & $-0,068$ & 1,000 & $-0,152$ & $-0,144$ & 0,046 & 0,043 \\
\hline zadovoljstvo & $-0,075$ & 0,012 & $-0,188$ & $-0,152$ & 1,000 & $-0,034$ & $-0,046$ & $-0,028$ \\
\hline samostojnost & 0,180 & $-0,097$ & 0,167 & $-0,144$ & $-0,034$ & 1,000 & 0,050 & 0,008 \\
\hline finančni viri & $-0,134$ & $-0,002$ & 0,035 & 0,046 & $-0,046$ & 0,050 & 1,000 & $-0,116$ \\
\hline regulativni ukrepi & 0,069 & 0,012 & 0,007 & 0,043 & $-0,028$ & 0,008 & $-0,116$ & 1,000 \\
\hline
\end{tabular}

starost in stanovanjski položaj, so prikazane v preglednici 4 . Presenetljivo je, da iz rezultatov izhaja, da je večina udeležencev, ki živi v skupnem gospodinjstvu, tako v Srbiji (povprečna stopnja strinjanja je 1,16) kot v Sloveniji (povprečna stopnja strinjanja je 1,24) ženskega spola, medtem ko na Japonskem prevladuje moški spol (povprečna stopnja strinjanja je 1,43), kar je v nasprotju s starejšimi ugotovitvami znanstvenikov (Takahashi in Voss, 2000; Suzuki, 2003; Raymo in Ono, 2004, Takada 2004, in Fukuda, 2007), po katerih naj bi bilo za to azijsko državo značilno, da se ženske poročajo pri nižji starosti kot moški, da pa moški prej zapuščajo dom staršev. Kot vzrok za slednje navajajo šolanje in zaposlitev. Novejše raziskave $\mathrm{v}$ japonskem kulturnem okolju pa kažejo (Hirayama, 2008, ter Yuichiro idr., 2015), da ni presenetljivo, da obstajajo razlike med spoloma v stopnji lastništva stanovanj, saj so šele dogodki, povezani z gospodarsko krizo na Japonskem, omogočili lastništvo tudi samskim ženskam, kar je, kot navajajo, posledica padca vrednosti premoženja, nižjih obrestnih mer in deregulacije posojil (spremenjena pravila $\mathrm{v}$ povezavi $\mathrm{s}$ poznejšo poroko). Za Srbijo in Slovenijo pa razliko v spolu pojasnjujemo z ugotovitvami Rudija Klanjška (2013), ki navaja, da čeprav mladi moški zaslužijo več kot mlade ženske glede na zaposlitveni status, razlike še vedno padajo, $s$ čimer se Slovenija uvršča med države, v katerih so pri plačah najmanjše razlike med spoloma. Glede na družinski položaj med udeleženci, ki bivajo pri starših, je izražena stopnja strinjanja med Slovenci in Srbi uravnotežena, medtem ko pri Japoncih prevladujejo samski udeleženci (povprečna stopnja strinjanja je 1,00). Zanimivo je, da vsi udeleženci navajajo izjemno nizko mesečno porabo sredstev za reševanje stanovanjskega proble- 
Preglednica 4: Povprečne stopnje strinjanja pri dejavnikih, pri katerih se kažejo statistično pomembne razlike glede na pripadnost kulturi, starost in lastništvo stanovanja, $v$ katerem udeleženci trenutno bivajo.

\begin{tabular}{|c|c|c|c|c|c|}
\hline status nepremičnine & lastna & tržni najem & neprofitni najem & pri sorodnikih & drugo \\
\hline \multicolumn{6}{|l|}{ spremenljivke } \\
\hline \multicolumn{6}{|l|}{ spol } \\
\hline Slovenci & 1,42 & 1,59 & 1,50 & 1,24 & 1,30 \\
\hline Srbi & 1,24 & 1,27 & & 1,16 & 1,50 \\
\hline Japonci & 2,00 & 2,00 & 2,00 & 1,43 & 1,50 \\
\hline \multicolumn{6}{|l|}{ družinski položaj } \\
\hline Slovenci & 1,48 & 1,41 & 1,36 & 1,47 & 1,41 \\
\hline Srbi & 1,43 & 1,45 & & 1,60 & 1,50 \\
\hline Japonci & 1,00 & 1,00 & 1,00 & 1,00 & 1,00 \\
\hline \multicolumn{6}{|l|}{ mesečna poraba } \\
\hline Slovenci & 1,67 & 3,05 & 2,07 & 1,40 & 2,07 \\
\hline Srbi & 2,19 & 2,14 & & 1,00 & 1,00 \\
\hline Japonci & 1,00 & 2,25 & 2,00 & 1,43 & 2,00 \\
\hline \multicolumn{6}{|l|}{ zadovoljstvo } \\
\hline Slovenci & 3,92 & 3,70 & 2,86 & 3,62 & 3,07 \\
\hline Srbi & 4,03 & 3,00 & & 4,00 & 4,50 \\
\hline Japonci & 3,67 & 4,00 & 2,00 & 4,00 & 2,50 \\
\hline \multicolumn{6}{|l|}{ občutek samostojnosti } \\
\hline Slovenci & 3,14 & 3,77 & 3,21 & 4,22 & 4,32 \\
\hline Srbi & 4,33 & 4,50 & & 4,60 & 4,25 \\
\hline Japonci & 4,33 & 3,25 & 2,00 & 4,00 & 4,00 \\
\hline \multicolumn{6}{|l|}{ finančni viri } \\
\hline Slovenci & 1,94 & 1,98 & 2,00 & 2,08 & 2,14 \\
\hline Srbi & 2,22 & 2,32 & & 1,80 & 2,75 \\
\hline Japonci & 1,33 & 1,25 & 2,00 & 1,71 & 1,50 \\
\hline \multicolumn{6}{|c|}{ regulativni ukrepi države } \\
\hline Slovenci & 2,12 & 2,00 & 2,07 & 2,19 & 2,18 \\
\hline Srbi & 2,06 & 2,27 & & 1,60 & 1,75 \\
\hline Japonci & 2,33 & 1,75 & 2,00 & 2,79 & 1,50 \\
\hline
\end{tabular}

ma (manj kot $30 \%$ ), kar pojasnjujemo z ugotovitvami M. Ule in M. Kuhar (2003), da mladi v povprečju uživajo doma pri starših dobršno mero avtonomije. Starši naj bi bili tisti, ki se trudijo zapolniti posledice razgradnje predhodne univerzalne države blaginje (Kovacheva, 2006), kar lahko pojasnjuje izjemno nizko izraženo povprečno stopnjo strinjanja pri srbskih udeležencih. V Sloveniji so povprečni stanovanjski stroški že presegli $30 \%$ razpoložljivega dohodka gospodinjstva, in sicer so ti v letu 2005 znašali 30,8 \%, v letu 200631,3 \% in v letu 2013 31,8 \% (Statistični urad Republike Slovenije, 2014). $\mathrm{Na}$ Japonskem pa se povprečni stanovanjski stroški gibljejo od $17,6 \%$ v letu 2001 do slabih $18 \%$ v letu 2013 (Official Statistic of Japan, 2014). Bistvena medkulturna razlika $v$ mesečni porabi sredstev za reševanje stanovanjskega problema lahko kaže različna pričakovanja in možnosti vstopa udeležen- cev v lastniški nepremičninski fond. Glede izražene stopnje strinjanja udeležencev, ki živijo s starši, vsi izražajo visoko stopnjo zadovoljstva (povprečna stopnja strinjanja pri Srbih in Japoncih je celo 4,0). Navedeno pojasnjujemo z rezultati raziskave K. Ramovš (2013), ki ugotavlja, da med prebivalci Slovenije, ki so starejši od 50. let, prevladuje stališče, da starejši in mlajši drug drugega enako dobro razumejo. Kot navaja Lavrič (2011), so slovenski mladostniki med tistimi v Evropski uniji, ki imajo najboljše odnose s starši. Raziskave tudi kažejo, da v Sloveniji ob neugodnih razmerah na trgu dela in dolgem izobraževanju k dolgemu sobivanju s starši pripomorejo predvsem sorazmerno ugodne možnosti bivanja (večinoma v hišah) in s tem nizka pripravljenost mladih na prevzemanje tveganja revščne v zgodnjem obdobju ustvarjanja lastnega gospodinjstva (Lavrič, 2011). 
Med finančnimi viri za nakup stanovanja izražajo Slovenci največjo stopnjo strinjanja glede financiranja s kreditom (stopnja strinjanja je 2,08), medtem ko Srbi in Japonci računajo tudi na svoja finančna sredstva (stopnja strinjanja je 1,80 oziroma 1,71). V številnih raziskavah je pogosto mogoče zaznati, da se mlajše generacije v Sloveniji odločajo za nakup nepremičnine s tujimi viri financiranja (Cvijanovič, 2010; Temeljotov Salaj in Črne, 2010, ter Grum in Čebular, 2015), saj se je ponudba bank na področju stanovanjskega kreditiranja $\mathrm{z}$ razvojem hipotekarnega kredita dobro razvila. Pri ročnosti tudi do 30 let, in sicer do 75. leta starosti, je mogoče že ob povprečnem osebnem dohodku pridobiti finančna sredstva, ki zadoščajo za nakup povprečnega stanovanja. Hipotekarni kredit je mogoče zavarovati s katero koli nepremičnino, ki je v Sloveniji in prosta bremen, tudi z nepremičnino, ki je predmet nakupa. Finančne ustanove različno pristopajo $\mathrm{k}$ razvrščanju zavarovalnega trga, $\mathrm{v}$ primeru kredita predvsem po motivu zadovoljevanja varnosti. Nemška zavarovalnica Alte Leipzinger loči razvrščanje glede na potrebe po preskrbljenosti družine, potrebe po preskrbljenosti v starosti, potrebe oseb z nadpovprečnimi dohodki, potrebe oseb s podpovprečnimi dohodki, potrebe samozaposlenih in posebne potrebe. $V$ primeru Slovenije, $v$ kateri je razmerje med aktivnim in upokojenim prebivalstvom za leto 2010 znašalo že 1,64: 1 , so omenjene raziskave pokazale visok trend pričakovanja pomoči starejše generacije pri reševanju prvega stanovanjskega problema mladih. Po drugi strani pa raziskava Boštjana Kerblerja (2014) kaže, da je uskladitev morebitnih strukturnih vrzeli med grajenim okoljem in staranjem prebivalstva izjemno pomembna. Ena od glavnih značilnosti stanovanj za potrebe vse starejše družbe je primerna cenovna dostopnost stanovanj ter zagotavljanje bistvenih in cenovno ugodnih storitev. In tu lahko obe generaciji poiščeta soodvisnost za reševanje problema. Hsuan Hsu (2006) je raziskoval, kako lastništvo gospodinjstev vpliva na stanovanjsko politiko, in ugotovil, da je za japonsko kot azijsko deželo značilen družbeni pojav medgeneracijskega prenosa lastninske pravice, kar lahko pojasni morebitno visoko izkazano pričakovanje finančne pomoči $s$ strani sorodnikov.

Glede regulativnih ukrepov države in njene pomoči mladim pri stanovanjskem osamosvajanju največjo stopnjo strinjanja izražajo Japonci (povprečna stopnja strinjanja je 2,79), najnižjo pa Srbi (povprečna stopnja strinjanja je 1,60). Jan Rouwendal in Simonetta Longhi (2008) to razliko pripisujeta spremenljivki, ki pri potrošnikih splošno psihološko izraža občutek optimizma ali pesimizma. Čeprav v Sloveniji kazalnik gospodarskega vzdušja za leto 2013 kaže stabilizacijo in ponovno rahlo rast, kazalnik zaupanja v gradbeništvo pa umerjanje (Statistični urad Republike Slovenije, 2014), ni rečeno, da bodo izražena pričakovanja udeležencev temu sledila (Grum, 2014). Tudi za Japonsko je značilno, da se zaupanje kupcev v nepremičninski trg počasi vrača, zato se pričakuje okrevanje stanovanjskega nepremičninskega trga (Global Property Guide, 2015). Indeks zaupanja potrošnikov (Economic and Social Research Institute, 2014), ki ga na Japonskem mesečno izračunavajo s pomočjo izvajanja ankete, kaže, da je zaupanje potrošnikov v letih 2006, 2007 in 2008 nenehno padalo, pozneje pa se je ustalilo. Regulativni ukrepi države vplivajo tudi na starost pri vstopu posameznika v lastno gospodinjstvo. Raziskave kažejo (Deutsch idr., 2005), da je povprečna starost Japonca, ko vstopa v svoje gospodinjstvo, blizu 40 let, kar je več kot v drugih državah. To naj bi bilo posledica bančne politike, ki določa maksimalno obremenitev osebnega dohodka do $25 \%$ in minimalno lastno udeležbo pri nakupu nepremičnine do višine $20 \%$ vrednosti nepremičnine, in visokih cen nepremičnin. Dosegljivost stanovanj ni problematična le pri obremenitvi dohodka s stanovanjskimi stroški, težave so tudi pri zagotavljanju primerne ponudbe stanovanj (Mandič, 2009). Gospodinjstva se pri tem soočajo z izrazito nezadostno ponudbo neprofitnega sektorja, majhno razpoložljivostjo službenih stanovanj, dragimi tržnimi najemniškimi stanovanji in visokimi cenami lastniških stanovanj (Mandič, 2009, in Gibson, 2013). Neugodna gospodarska gibanja po letu 2008 so spremenila gospodarske dejavnosti v vseh treh opazovanih državah. Po mnenju Alenke Kajzer (2009) je to pomembno vplivalo na trg dela, zaznane pa so bile tudi spremembe $\mathrm{v}$ gibanju plač. Zaradi naraščanja brezposelnosti se je država Slovenija odzvala tako, da je okrepila izvajanje programov aktivne politike zaposlovanja. Sprejeta sta bila intervencijska zakona, namenjena ohranjanju delovnih mest. Januarja 2009 je bil sprejet Zakon o delnem subvencioniranju polnega delovnega časa (Ur. l. RS, št. 5/2009), konec maja istega leta pa Zakon o delnem povračilu nadomestila plače (Ur. l. RS, št. 42/2009). Japonska vlada se je s krizo spoprijela tako, da je v letu 2009 sprejela stimulativni ukrep, vreden 173 milijard ameriških dolarjev, kar je več, kot je znašala skupna vrednost vseh ukrepov v letu 2008 (Global Property Guide, 2009). Vse navedeno je vplivalo na gibanja realne stopnje rasti bruto domačega proizvoda, zanimive pa so ugotovitve raziskave Wonga in Hiuja (2006), v kateri je kar $95 \%$ japonskih udeležencev odgovorilo, da so pri odločanju za nakup stanovanja pomembni dejavniki, kot so finančno stanje, obrestna mera in družinski prihodki, skoraj v celoti po so prezrli vprašanje o stopnji brezposelnosti, ki je bila med izvajanjem navedene ankete zelo visoka. Naši rezultati tako niso v skladu z rezultati raziskav, ki jih povzema Klanjšek (2014), ki navaja, da je slovenska mladina $\mathrm{v}$ primerjavi drugimi postjugoslovanskimi državami bolj pesimistična glede gospodarskega položaja države v prihodnosti. Hkrati pa bi nizko stopnjo strinjanja glede regulativnih ukrepov države in njene pomoči mladim pri stanovanjskem osamosvajanju pri Srbih (in tudi pri Slovencih) lahko pojasnili s povzetki kvantitativne raziskave Andreja Natererja (2011), ki navaja, da mladi (generacija Y) doživljajo stanje, v katerem so se znašli, kot razmeroma neugodno in težko, še posebej, če se primerjajo z generacijo X (tako imenovani 
babyboomerji). Prepričani so, da je bilo odraščanje predhodnih generaciji lažje, da je bilo to takrat družbeni projekt, ki je zagotovil vse, kar je po njihovem mnenju pomembno za osamosvojitev: služba, stanovanje in pokojnina. Zato mladi danes vidijo družbo kot nezanesljivega, včasih celo nekoliko zahrbtnega partnerja, s katerim je treba za sodelovanje skleniti formalnopravno pogodbo, saj zaupanje in dobri odnosi ne zadostujejo več. Tako zanje spet postanejo pomembni partnerji starši, in kot ugotavlja Naterer (2011), se za sobivanje generacij zdi, da to ni izraz razvajenosti mladih ali permisivnosti vzgoje, ampak oblika dobrega medgeneracijskega sodelovanja.

Naša raziskava torej potrjuje hipotezo, da bivanje mladih in starih v razširjeni družini ni pokazatelj dobrega medgeneracijskega sožitja in solidarnosti, ampak prej izraža širše družbene in kulturne procese, ki uravnavajo življenje vse družbe in posameznikov.

\section{Sklep}

Gospodarske, družbene, kulturne, politične in demografske spremembe pomembno vplivajo na tradicionalno družino ter družbene strukturne in medgeneracijske odnose, to pa se kaže tudi v vse pomembnejšem problemu skupnega gospodinjstva oziroma podaljšanega sobivanja mladih družin in staršev. V članku smo zato raziskovali strukturalne dejavnike in individualne razloge, ki vplivajo na podaljšano sobivanje mladih $\mathrm{v}$ skupnem gospodinjstvu s starši. V tem okviru smo analizirali željo mladih, namen, način in njihova pričakovanja po odselitvi »na svoje «. Zanimalo nas je, ali menijo, da bi jim država z regulativnimi ukrepi morala pri tem pomagati. Izhajamo iz hipoteze, da bivanje mladih in starih $\mathrm{v}$ razširjeni družini ni pokazatelj dobrega medgeneracijskega sožitja in solidarnosti, ampak prej izraža širše družbene in kulturne procese, ki uravnavajo življenje vse družbe in posameznikov. Kot osrednji raziskovalni pripomoček smo uporabili vprašalnik, ki smo ga oblikovali sami. Raziskava je potekala v treh različnih kulturnih okoljih v Sloveniji, Srbiji in na Japonskem. V njej je sodelovalo 1.006 slovenskih udeležencev, 385 srbskih in 264 japonskih. $V$ vzorec so bili vključeni udeleženci, ki so bili stari od 20 do 40 let ter smo jih razdelili po spolu, izobrazbi, družbenem in finančnem položaju, zakonskem oziroma družinskem položaju, bivalnem okolju in kulturni pripadnosti.

Rezultati kažejo statistično pomembne razlike pri spolu mladih, ki živijo v skupnem gospodinjstvu. V Srbiji in Sloveniji prevladuje ženski spol (povprečna stopnja strinjanja je 1,24), na Japonskem pa moški (povprečna stopnja strinjanja je 1,43). Navedeno kaže na bistvene demografske spremembe, do katerih je prišlo v japonski družbi v zadnjih desetih letih. Statistično pomembne razlike se kažejo pri vprašanju glede pričakovanja pomoči države z regulativnimi ukrepi. Največjo stopnjo strinjanja izražajo Japonci (povprečna stopnja strinjanja je 2,79), najnižjo pa Srbi (povprečna stopnja strinjanja je 1,60). Znanstveniki to razliko pripisujejo spremenljivki, ki pri potrošnikih psihološko izraža občutek optimizma ali pesimizma. Čeprav v Sloveniji kazalnik gospodarskega vzdušja in zaupanja v gradbeništvo kaže umerjanje, pa ni rečeno, da bodo izražena pričakovanja udeležencev temu sledila. Za Japonsko pa je značilno, da se zaupanje kupcev v nepremičninski trg vrača, zato se tudi v bližji prihodnosti pričakuje okrevanje stanovanjskega nepremičninskega trga. Indeks zaupanja potrošnikov na Japonskem kaže, da zaupanje potrošnikov od leta 2013 naprej raste. Statistično pomembne razlike se kažejo tudi glede na izraženo zadovoljstvo $s$ trenutnimi stanovanjskimi pogoji, glede izraženega občutka samostojnosti, glede na družinski položaj, mesečno porabo za reševanje stanovanjskega problema in pri načrtovanih glavnih virih pri nakupu lastnega stanovanja. Glede izražene stopnje strinjanja udeležencev, ki živijo s starši, najvišjo stopnjo zadovoljstva izražajo Srbi in Japonci (povprečna stopnja strinjanja je celo 4,0), med finančnimi viri za nakup stanovanja pa izražajo največjo stopnjo strinjanja glede financiranja s kreditom slovenski udeleženci (stopnja strinjanja je 2,08), medtem ko srbski in japonski udeleženci računajo tudi na svoja finančna sredstva (stopnja strinjanja je 1,80 oziroma 1,71). Hsu (2006) je raziskoval, kako lastništvo gospodinjstev vpliva na stanovanjsko politiko, in ugotovil, da je za Japonsko kot azijsko deželo značilen družbeni pojav medgeneracijskega prenosa lastninske pravice, kar lahko pojasni visoko izkazano pričakovanje finančne pomoči s strani sorodnikov. Ugotavljamo pa, da bistvena medkulturna razlika glede na mesečno porabo sredstev za reševanje stanovanjskega problema lahko kaže tudi različna pričakovanja in možnosti vstopa udeležencev v lastniški nepremičninski fond oziroma samostojno gospodinjstvo.

Raziskava je pokazala, da si mladi, ki bivajo v skupnem gospodinjstvu s starši, tudi če se z njimi relativno dobro razumejo, želijo »na svoje «. Pri tem pričakujejo večjo pomoč države, ki bi z regulativnimi ukrepi in pravično porazdeljeno socialno pomočjo med »mlado « in »staro « generacijo vodila socialno bolj pravično in mladim družinam prijaznejšo stanovanjsko politiko. $S$ tem bi se zmanjšal pritisk na družino in možnosti za napetosti v njej, kot tudi za napetosti med državo in družino. Kot navaja Richard Sendi (2013), povzroča prenaseljenost stanovanj slabo počutje, zdravstvene težave ipd., zato mora Slovenija na tem področju hitro ukrepati ter pri tem upoštevati najnovejšs pristope pri načrtovanju stanovanj in zagotavljanju ustreznega standarda. Raziskava tudi kaže, da se pomembni koraki pri tradicionalnem prehajanju v odraslost pojavljajo $\mathrm{v}$ nekoliko drugačnem zaporedju, kot je bilo značilno za starejše generacije, najprej dokončanje šole, nato vstop na stabilni trg 
delovne sile, selitev od doma in šele nato oblikovanje družine. Pri tem država ne bi smela pozabiti na pomen osamosvajanja glede na stopnjo rodnosti v državi. Navedeno korelacijo potrjuje tudi primer Japonske, kjer je povprečna starost mladih, ko gredo na svoje, med opazovanimi kulturami najvišja (40 let). Za Japonsko pa je tudi značilno, da je najhitreje starajoča se družba. Mladi mislijo, da je bilo odraščanje starejših generaciji lažje, da je bilo to takrat družbeni projekt, ki je zagotovil vse, kar je po njihovem mnenju pomembno za osamosvojitev: služba, stanovanje in pokojnina. Zato danes gledajo na družbo kot na nezanesljivega, včasih celo nekoliko zahrbtnega partnerja, s katerim je treba za sodelovanje skleniti formalnopravno pogodbo, saj zaupanje in dobri odnosi ne zadostujejo več. Tako zanje spet postanejo pomembni partnerji starši, in kot ugotavlja Naterer (2011), se za sobivanje generacij zdi, da to ni izraz razvajenosti mladih ali permisivnosti vzgoje, ampak oblika dobrega medgeneracijskega sodelovanja. Naša raziskava torej potrjuje hipotezo, da bivanje mladih in starih v razširjeni družini ni pokazatelj dobrega medgeneracijskega sožitja in solidarnosti, ampak prej izraža širše družbene in kulturne procese, ki uravnavajo življenje vse družbe in posameznikov.

Bojan Grum

Evropska pravna fakulteta, Pravo in management nepremičnin, Ljubljana, Slovenija

E-pošta: bgrum@siol.net

Alenka Temeljotov Salaj

HIOA - Oslo and Akershus, University College of Applied Sciences, Oslo, Norveška

E-pošta: alenka-temeljotov.salaj@hioa.no

\section{Viri in literatura}

Allen, J., Barlow, J., Leal, J., Maloutas, T., in Padovani, L. (2004): Housing and Welfare in Southern Europe. Oxford, Blackwell Publishing Ltd. DOI: $10.1002 / 9780470757536$

Aassve, A., lacovou, M., in Mencarini, L. (2006): Youth poverty and transition to adulthood in Europe. Demographic Research, 15(2), str. 2150. DOI: 10.4054/DemRes.2006.15.2

Bianchi, S. M., in Casper, L. M. (2000): American Families. Population Bulletin, 55(4), str. 3-43.

Biggart, A., Bendit, R., Caruso, D., Hein, K., in Morch, S. (2004): Families and transitions in Europe. Research report. Lizbona, Instituto de ciencias sociais, Universidade de Lisbona.

Brandt, M., Haberkern, K., in Szydlik, M. (2008): Soziale Dienste und Hilfe zwischen Generationen in Europa (Social services and help between generations). Zeitschrift fur Soziologie, 37(4), str. 301-20.

Bratina Jurkovič, N. (2014): Perception, experience and the use of public urban spaces by residents of urban neighbourhoods. Urbani izziv, 25(1), str. 107-125. DOI: 10.5379/urbani-izziv-en-2014-25-01-003

Cvijanovic, D. (2010): Stanovanjska problematika in stanovanjska oskrba mladih - primer mestne občine Nova Gorica. Magistrsko delo. Nova Gorica, Evropska pravna fakulteta.

Deutsch, E., Tiwari, P., in Moriizumi, Y. (2005): The slowdown in the timing of housing purchases in Japan in the 1990s. Journal of Housing Economics, 15(3), str. 230-256. DOI: 10.1016/j.jhe.2006.09.007

Economic and Social Research Institute (2014): Monthly consumer confidence survey covering all of Japan. Tokio.

Emmons, W. R., in Noeth, B. J. (2014): Housing crash continues to overshadow young families' balance sheets. St. Lois, Federal Reserve Bank of St. Louis or the Federal Reserve System.

European Union Labour Force Survey (2013): Annual results 2012. Newport.

Eurostat (2012): Europe in figures, Eurostat yearbook 2012. Luxembourg.

Forrest, R., Kennett, P. in Izuhara, M. (2003): Home ownership and economic change in Japan. Housing Studies, 18(3), str. 277-293. DOI: 10.1080/02673030304241

Fukuda, S. (2007): The socio-economic status of women and marital fertility in post-war Japan: Effects of education, employment and family structure on parity transitions. The Journal of Population Studies, 40(2), str. 79-100.

Fulgosi, A. (1984): Faktorska analiza. Zagreb, Sveučilište u Zagrebu, Filozofski fakultet v Zagrebu.

Gibson, H. J. (2013): Rethinking the memorial in a Black Belt landscape: Planning, memory and identity of African Americans in Alabama. Urbani izziv, 24(1), str. 144-159. DOI: 10.5379/urbani-izziv-en-2013-24-01-004

Global Property Guide (2015): Japan: Despite a weak economy and a shrinking population, Abenomics is pushing house prices up. Tokio.

Global Property Guide (2009): House price falls in Japan accelerate. Tokio.

Goetegeluk, R., Hooimeijer, P., in Dieleman, F. (1992): The effectivenes of housing search: The role of motives for moving and housing market adjustment. Prispevek je bil predstavljen na konferenci z naslovom Europena Cities: Growth \& Decline, ki je potekala od 13. do 16. aprila v Haagu na Nizozemskem. Tipkopis.

Goldscheider, F. K. (1997): Recent changes in U.S. young adult living arrangements in comparative perspective. Journal of Family Issues, 18(special issue), str. 708-724. DOI: 10.1177/019251397018006008

Grum, B. (2014): Differences in demographic characteristics of potential acquirers of real estate rights: Cases from Slovenia and Japan. Current Urban Studies, 2(2), str. 105-115. DOI: 10.4236/cus.2014.22011

Grum, B., in Kobal Grum, D. (2015): A model of real estate and psychological factors in decision-making to buy real estate. Urbani izziv, 26(1), str. 82-91. DOI: 10.5379/urbani-izziv-en-2015-26-01-002

Grum, B., in Čebular, U. (2015): When buying residental property young people expect more help from the state: Case of Slovenia. International Journal of Social Science Studies, 3(1), str. 7-16.

Grum, B., in Temeljotov Salaj, A. (2010a): Pričakovanja potencialnih pridobiteljev nepremičninskih pravic v Republiki Sloveniji glede na njihov spol, starost, izobrazbo in zaposlenost. Geodetski vestnik, 54(3), str. 501-516.

Grum, B., in Temeljotov Salaj, A. (2010b): The external expectations of potential real estate buyers in Slovenia and Japan. Urbani izziv, 21(2), str. 106-116. DOI: 10.5379/urbani-izziv-en-2010-21-02-004

Hartley, R. (1993): Young adults living at home. Australian Institute of Family Studies, 36(1), str. 35-37.

Heath, S. (1999): Young adults and household formation in the 1990s. British Journal of Sociology of Education, 20(4), str. 545-562. DOI: 10.1080/01425699995263

Hirayama, Y. (2008): Womenss marital status and housing tenure in the context of Japanss home-owning society. Journal of Architecture and Planning, 73(1), str. 1045-1052. DOI: 10.3130/aija.73.1045 
Holdsworth, C., in Morgan, D. (2006): Transitions in context: Leaving home,independence \& adulthood. Cambridge, Polity Press.

Hoxha, V., Dimitrovska Andrews, K., in Temeljotov Salaj, A. (2014): Cultural factors affecting urban planners' intentions to regulate public space in Prishtina, Kosovo. Urbani izziv, 25(2), str. 76-89.

DOI: 10.5379/urbani-izziv-en-2014-25-02-001

Hsu, P. H. (2006): How the source of home ownership affect political attitudes? V: Sendi, R., in Černič Mali, B. (ur.): Housing in an expanding Europe, str. 1-16. Ljubljana, Urbanistični inštitut Republike Slovenije.

Izahura, M. (2014): Life-course diversity, housing choices and constraints for women of the 'lost' generation in Japan. Housing Studies, 30(1), str. 60-77. DOI: 10.1080/02673037.2014.933780

Jian, G., in Kazunori, H. (2004): Residential environmental evaluation of local cities considering regional characteristic and personal residential preference - case study of Saga City. Journal of Environmental Sciences, 16(1), str. 138-144.

Jian, G., in Kazunori, H. (2006): Research on residential lifestyles in Japanese cities from the viewpoints of residential preference, residential choice and residential satisfaction. Landscape and Urban Planning, 78(3), str. 165-178. DOI: 10.1016/j.landurbplan.2005.07.004

Jolanki, O. (2015): Elderly parentss need for help and adult children's moving decisions. Journal of Housing for the Elderly, 29(1-2), str. 77-91. DOI: 10.1080/02763893.2015.989763

Kajzer, A. (2009): Odziv trga dela na recesijo v Sloveniji. IB Revija, $43(3-4)$, str. 69-76.

Keats, D. M. (2000): Interviewing, a practical guide for students and professionals. Buckingham, Open University Press, Celtic Court, Ballmoor.

Kerbler, B. (2014): An innovative built environment form for dwellings for the elderly. METU Journal of the Faculty of Architecture, 31(1), str. 119-137. DOI: 10.4305/metu.jfa.2014.1.6

Klanjšek, R. (2014): Bivalne razmere in socialno-ekonomski položaj mladine. V: Center za raziskovanje postjugoslovanskih družb Maribor (ur.): Mladina 2013: življenje v času deziluzij, tveganja in prekarnosti, str. 4-9. Maribor.

Kleinhans, R., in Elsinga, M. (2010): Buy your home and feel in control> dose home ownership achieve the empowerment of former tenants of social housing? International Journal of Housing Policy, 10(1), str. 41-61.

Klinc, R., Turk, Ž., in Dolenc, M. (2010): Raziskava o rabi informacijskokomunikacijskih tehnologij v Slovenski gradbeni industriji. Gradbeni vestnik, 59(11), str. 269-276.

Korpi, W. (2000): Faces of inequality: Gender, class, and patternes of inequalities in diferent types of welfare states. Social Polites: International Studies in Gender Stateand Society, 7(2), str. 127-191. DOI: 10.1093/ $\mathrm{sp} / 7.2 .127$

Kovacheva, S. (2006): Youth transitions and family support in a trans forming social context: Reflections from the New Member States. V: Lutz, W., Richter, R., in Wilson, C. (ur.): The new generations of Europeans: Demography and families in the enlarged European Union, str. 145-176. London, Sterling, Earthscan.

Kuhar, M. (2012): Podaljšano sobivanje staršev in mladih odraslih. Socialno delo, 51(6), str. 205-218.

Kuhar, M. (2013): Analiza dejavnikov podaljšanega sobivanja staršev in otrok v Sloveniji. Teorija in praksa, 50(5-6), str. 5-6.

Lavrič, M., in Klanjšek, R. (2013): Stanovanjske in bivalne razmere mladih. V: Center za raziskovanje postjugoslovanskih družb Maribor (ur.): Mladina 2013: življenje v času deziluzij, tveganja in prekarnosti, str. 282305. Maribor
Lavrič, M. (2011): Ključne ugotovitve študije Mladina 2010. V: Lavrič, M.(ur.): Mladina 2010 - Družbeni profil mladih v Sloveniji, str. 587-590. Ljubljana, Ministrstvo za šolstvo in šport, Urad Republike Slovenije za mladino in Založba Aristej.

Lobe, B. (2006): Mixing qualitative and quantitative methods in the environment of new information-communication technologies. Ljubljana, Fakulteta za družbene vede.

Mandič, S. (2007): Odhod v prvo samostojno stanovanje: primerjalna analiza med državami Evropske unije. Družboslovne razprave, 13(54), str. 7-24.

Mandič, S. (2009): Stanovanjske razmere mladih. V: Rakar, T., in Boljka, U. (ur.): Med otroštvom in odraslostjo, analiza položaja mladih v Sloveniji 2009, str. 77-93. Ljubljana, Urad Republike Slovenije za mladino in Inštitut Republike Slovenije za socialno varstvo.

Mandič, S., in Filipovič Hrast, M. (2015): Alternatives to social housing: Applicants' views of various policy options. Urbani izziv, 26(1), str. 6981. DOI: 10.5379/urbani-izziv-en-2015-26-01-001

Mulder, C. (2006): Housing and population: A two-sided relationship. Housing in an expanding Europe; theory, policy, participation and implementation. Ljubljana, Urbanistični inštitut Republike Slovenije.

Naterer, A. (2011): Zeitgeist mladih. V: Lavrič, M. (ur.): Mladina 2010 Družbeni profil mladih v Sloveniji, str. 579-586. Ljubljana, Ministrstvo za šolstvo in šport, Urad Republike Slovenije za mladino in Založba Aristej.

National Institute of Population and Social Security Research (2008): Latest Demographic Statistics 2008. Tokio.

Official Statistic of Japan (2014): Yearly average of monthly disbursements per household. Tokio.

Pompe, A., in Temeljotov Salaj, A. (2014): Qualitative criteria of urbanism and brands: A comparative analysis. Urbani izziv, 25(1), str. 74-92. DOI: 10.5379/urban-izziv-en-2014-25-01-001

Raymo, J. M. (2003): Premarital living arrangements and the transition to first marriage in Japan. Journal of Marriage and Family, 65(2), str. 302-315. DOI: 10.1111/j.1741-3737.2003.00302.x

Raymo, J. M., in Ono, H. (2004): Coresidence with parents, the "comforts of home," and the transition to marriage among Japanese momen. Madison, University of Wisconsin, Center for Demography and Ecology.

Ramovš, K. (2013): Medgeneracijsko sožitje in solidarnost. Kakovostna starost, 16(4), str. 3-33.

Rohe, W. M, Zandth, S., in McCarthy, G. (2001): The social benefits and costs of homeownership: A critical assessment of the research. Cambridge, Joint Center for Housing Studies of Harvard University.

Rouwendal, J., in Longhi, S. (2008): The effect of consumers expectations in a booming housing market: Space-time pattern in the Netherlands, 1999-2000. Housing Studies, 23(3), str. 291-317. DOI: $10.1080 / 02673030801893107$

Sang-arun, N. (2013): Development of regional growth centres and impact on regional growth: A case study of Thailand's Northeastern region. Urbani izziv, 24(1), 160-171.

DOI: 10.5379/urbani-izziv-en-2013-24-01-005

Sendi, R. (2013): The low housing standard in Slovenia: Low purchasing power as an eternal excuse. Urbani izziv, 24(1), str. 107-124. DOI: 10.5379/urbani-izziv-en-2013-24-01-002

Statistični urad Republike Slovenije (2014): Slovenija v številkah 2013. Ljubljana.

Stropnik, N., in Šircel, V. (2008): Slovenia: Generous family policy without evidence of any fertility impact. Demographic research, 19(7), str. 1019-1058. DOI: 10.4054/DemRes.2008.19.26 
Suzuki, T. (2003): Leaving home in Japan: Its trends, gender differences, and determinants. Journal of Population Problems, 59(1), str. 1-18.

Suzuki, T. (2007): Recent developments in household formation in Japan. Journal of Population Problems, 63(1), str. 1-13.

Takada, S. (2004): Living arrangements of single Japanese women: Are Japanese parents altruistic? Journal of Population Studies, 34(1), str. 1-11.

Takahashi, H, in Voss, J. (2000): Parasite singles: A uniquely Japanese phenomenon? JEl Report 31A, str. 1-12.

Temeljotov Salaj, A., in Črne, J. (2010): Tveganje posameznikov in družinske skupnosti ob najemu hipotekarnega kredita. Dignitas, 45-46(1), str. 193-214.

Tomanović, S., in Ignjatović, S., (2006): Attitudes on transition to adulthood among young people in Serbia. Sociologija, 48(1), str. 56-72.

DOI: $10.2298 /$ SOC0601055T

Ule, M., in Kuhar, M. (2003): Mladi, družina, starševstvo. Ljubljana, Fakulteta za družbene vede.

van Ommerren, J., Rietveld, P., Nijkamp, P., in Mobility, J. (2000): Residential mobility and commuting. Annals of Regional Sciences, 34(2), str. 213-232. DOI: 10.1007/s001689900004

Vogel, J. (2002): European welfare regimes and the transition to adulthood. Social Indicators Research, 59(3), str. 275-299. DOI: 10.1023/A:1019627604669

Waldron, V. R., Gitelson, R., Kelley, D., in Regalado, J. (2005): Losing and building supportive relationships in later life: A four-year study of migrants to a planned retirement community. Journal of Housing for the Elderly, 19(2), str. 5-25. DOI: 10.1300/J081v19n02_02

Walker, A. (2006): Active ageing in employment: Its meaning and potential. Asia Pacific Review, 13(1), 78-93. DOI: 10.1080/13439000600697621

Walonic, D. S. (2007): Survival statistic. Bloomington, StatPac, Inc.

Wong, J. T. Y., in Hui, E. C. M. (2006): Research notes - power of expectations. Property Management, 24(5), str. 496-506. DOI: 10.1108/02637470610710547

Yau, Y. (2015): The value of building safety: A hedonic price aproach. Urbani izziv, 26(1), str. 92-104.

DOI: 10.5379/urbani-izziv-en-2015-26-01-003

Yuichiro, l., Ichiro, M., in Yasutaka, T. (2015): Data analysis for monitoring Japan's real estate market. Tokio. 